\title{
O acompanhamento psicológico a familiares de pacientes oncológicos terminais no cotidiano hospitalar
}

\author{
André Luiz Picolli da Silva \\ Universidade Federal de Santa Catarina
}

\begin{abstract}
Resumo
Nossa sociedade atual tem-se demonstrado cada vez mais inábil em lidar com as questões referentes à morte, sendo esta, muitas vezes, vista como algo antinatural que não deve ser lembrado. Essa situação faz com que nos tornemos despreparados frente à realidade da finitude humana, não sabendo como reagir quando subitamente nos deparamos com situações de morte iminente, principalmente quando esta morte ocorre com entes queridos. Neste artigo pretende-se aclarar as dificuldades do trabalho com familiares enlutados, de pacientes terminais com câncer em hospitais gerais, bem como fornecer orientações práticas aos psicólogos que atuam na área. O trabalho de luto em si, já apresenta dificuldades que, juntas ao estigma de uma doença secular, a agressividade da situação cirúrgica aliada a um ambiente hospitalar aversivo, criam um universo riquíssimo para o surgimento das mais variadas fantasias, conflitos pessoais e quadros patológicos, sendo estes alguns dos principais objetos de intervenção, com os quais o psicólogo se depara no âmbito hospitalar.
\end{abstract}

Palavras-chave: luto; câncer; hospital.

\section{Abstract \\ The psychologist's support to families in their morning process for relatives having terminal cancer}

Nowadays, our society has manifested more and more inaptness in dealing with death issues. When we are suddenly faced with the imminent death of a loved one, we feel unprepared and don't know how to react. This article highlights the difficulties of working with a family's bereavement process for terminally ill cancer patients and provides practical orientation for psychologists who work in surgical clinics of general hospitals. The bereavement process has its own difficulties, besides the stigma of a secular disease, and the aggressiveness of a surgical situation, allied with a repulsive environment, can create a very a condition in which there is o the appearance of fantasies, personal conflicts and pathological frame of mind. These are some of the principal objects for intervention which the psychologist must face himself/herself in the hospital ambit.

Keywords: mourning, cancer; hospital.

\section{A CONSTRUÇÃO DE UM PENSAMENTO EQUIVOCADO}

Quando nos remetemos à terminologia "pacientes terminais", geralmente surge em nosso pensamento, a questão da morte, e na maioria dos casos um medo quase incompreensível da mesma. Esse medo originase pela negação da morte, na tentativa de se reviver uma vida que não foi vivida, pelo medo da vida. Essa forma de encarar a vida e a morte não é um fenômeno específico surgido nesse atual momento histórico do início do século XXI; ao invés disso, a situação de despreparo frente a tais questões foi construída ao longo dos séculos dentro da civilização ocidental. Nossa cultura desenvolveu-se sobre uma estrutura social baseada na repressão, sobretudo a corporal que está presente entre nós desde os primórdios de nossa civilização, sendo apenas refinada ao longo dos séculos.

\begin{abstract}
Nas culturas de coleta não se trabalhava sistematicamente. Por isso os controles eram frouxos e podia-se viver mais prazerosamente. Quando o homem começa a dominar a natureza, ele começa a se separar dessa mesma natureza em que até então vivia imerso. Como o trabalho é penoso, necessita agora de um poder central que imponha controles mais rígidos e punição para a transgressão. É preciso usar a coerção e violência para que os homens sejam obrigados a trabalhar, $e$ essa coerção é localizada no corpo, na repressão da sexualidade e do prazer (Muraro, 1991, p. 9).
\end{abstract}

Assim, para conseguir um domínio sobre a natureza o homem ocidental distanciou-se dela, construindo então, a raiz de nosso primeiro grande medo, ou seja, o medo da vida, demonstrado e ocasionado pela repressão da sexualidade. Isto, mais tarde, fará surgir nosso segundo grande medo, ou seja, o da morte, demonstrado e ocasionado pela necessidade de aumentar o tempo de vida na busca de 
um prazer que não é encontrado. Essas questões, sobre vida e a morte, durante séculos ficaram submetidas ao domínio quase exclusivo da religião e da filosofia. Com o surgimento da dicotomia cartesiana $\mathrm{e}$ posteriormente com o advento do capitalismo, as questões referentes à vida e à morte foram transferidas para o domínio da ciência e, para a medicina, como sua representante oficial para esses assuntos. Pode-se supor então, que foi a partir desse período que a vida e a morte começaram a ser pautadas apenas sobre $\mathrm{o}$ corpo, que passava a ter um outro significado: o da força de trabalho.

Porém, no início do surgimento dos grandes hospitais gerais, estes ainda estavam ligados à religiosidade, havendo uma divisão na figura e função da medicina. O médico mantenedor da saúde era aquele que visitava a casa de seus pacientes, realizando ali o tratamento. O hospital, por sua vez, realizava mais obras assistencialistas (e de limpeza do rejeito da sociedade), sendo que o tratamento oferecido ali era, mais uma obra de caridade do que uma busca pela saúde propriamente dita.

O personagem ideal do hospital até o século XVIII não é o doente que é preciso curar, mas o pobre que está morrendo. É alguém a quem se deve dar os últimos cuidados e os últimos sacramentos. Esta é a função essencial do hospital. Dizia-se corretamente nessa época que o hospital era um morredouro, um lugar onde morrer. E o pessoal hospitalar não era fundamentalmente destinado a realizar a cura do doente, mas conseguir a sua própria salvação. Era um pessoal caritativo - religioso ou leigo - que estava no hospital para fazer uma obra de caridade que lhe assegurasse à salvação eterna (Pitta, 1999, p. 41).

Com o tempo a visão religiosa foi cedendo espaço para a visão do capital e, o controle sobre o corpo que produz, transformou-se em uma fonte ainda maior de poder. Dessa forma, o hospital passou gradativamente de uma forma de assistencialismo, para uma forma de domínio e controle social.

Trata-se de recolher, alojar, alimentar aqueles que se apresentam de espontânea vontade, ou aqueles que para lá são encaminhados pela autoridade real ou judiciária. É preciso também zelar pela subsistência, pela boa conduta, e pela ordem geral daqueles que não puderam encontrar seu lugar ali, mas que poderiam ou mereciam ali estar. Essa tarefa é confiada a diretores nomeados por toda a vida, e que exercem seus poderes não apenas nos prédios do hospital como também em toda a cidade de Paris sobre todos aqueles que dependem de sua jurisdição (Foucault, 1999, p. 49).

Sendo o corpo agora visto como uma máquina que produz, quanto mais tempo tal máquina produzisse a um baixo custo, melhor para o coletivo onde essa máquina estava inserida. O hospital, desse modo, desviou sua atuação de depósito do rejeito social ou de lugar de caridade, para se tornar o local de manutenção de corpos. A função médica que nos primórdios hipocráticos era a de mantenedora da vida, foi distorcida para a mantenedora da força produtiva. Com o tempo, a sociedade legitimou e incorporou essa forma de pensar, e a idéia de vida boa sendo igual à vida longa (e produtiva) passou a fazer parte do cotidiano. Tal pensamento continua impregnado em nossa conduta social, mesmo depois das revoluções industriais (quando a partir de então, a força humana, pelo menos em tese não seria tão requerida), acabando por "atingir" as modernas equipes de saúde que, apresentam inabilidade para tratar de questões referentes à morte, tentando a todo o custo, apenas prolongar o tempo de vida.

Observa-se desse modo, que a sociedade como um todo, através de um processo de adoecimento da vontade, passou a ter uma utilização distorcida da vida, e num complexo sistema estóico de postergação do prazer, acaba por não viver a vida e conseqüentemente não pensando na morte. Quando o indivíduo se depara com o inevitável, ou seja, com a morte, fica confuso diante do desconhecido e, geralmente não consegue expressar reações diferentes do estupor ou raiva.

\section{O CÂNCER E O PACIENTE}

O câncer é uma patologia caracterizada pela proliferação descontrolada de células anormais que invadem as estruturas das células vizinhas espalhando-se continuamente, bem como, pela sua disseminação a distância (metástase), por intermédio da corrente sangüínea, vasos linfáticos ou cavidades do organismo. A razão pela qual certas células de um momento para outro começam a proliferar de forma desordenada ainda não é bem conhecida, sabe-se apenas que o DNA da célula sofre um processo mutacional (causado por uma lesão), que faz com que esta não responda mais ao controle intracelular, transformando-se assim, em um oncogene que prolifera e contamina as células adjacentes. Casciato e Lowitz (1991) fornecem um exemplo simples de como se desenvolve um oncogênese através de uma contaminação viral.

\begin{abstract}
Vários tipos de vírus produzem câncer em animais $e$ crescimento de células anormais em culturas de tecidos. Os retrovirus são os mais estudados, estes vírus são RNA simples apresentando um código genético para transcriptase reserva - uma enzima que produz DNA, utilizando o RNA viral como modelo. Este DNA pode ser incorporado ao genoma da célula hospedeira, reproduzindo muitas cópias do RNA viral original. O DNA viral também pode combinar-se com o DNA do genoma da célula, produzindo novos vírus RNA que contém cópias do RNA do genoma da célula hospedeira normal. Estes novos vírus infectam outras células do hospedeiro, provocando a transformação maligna. Foi denominado oncogênese o gene do hospedeiro transformado e incorporado ao vírus (Casciato \& Lowitz, 1991, p. 50).
\end{abstract}

A partir dos oncogene surgem várias novas células contaminadas, denominadas "neoplasias" que, posteriormente poderão desenvolver diferentes tipos 
de tumores, tais como os carcinomas, sarcomas, melanomas etc. Atualmente, os principais fatores conhecidos que podem causar mutação no DNA das células, segundo Casciato e Lowitz (1991, pp. 3-5) são:

Agentes dietéticos - Gordura, ingestão calórica total elevada, proteína animal, álcool, conservas salgadas/defumadas e aditivos a base de nitrato e nitrito.

Agentes químicos - Tabagismo, aflotoxinas (do Aspergillus, que pode contaminar amendoins), animas aromáticas e corantes de anilina, arsênico etc.

Agentes farmacológicos - Agentes alquilinantes, esteróides anabólicos, arsênico, contraceptivos orais, drogas imunossupressoras e fenacitina etc.

Agentes microbianos - Citomegalovírus, vírus da hepatite B, HTLV-1, HTLV-2, HTLV-3, HIV, papiloma vírus e schistosoma haemotobium etc.

Além destes agentes, Chabner (1993, pp. 1.0481.051) cita também, outros fatores associados ao surgimento de células cancerígenas:

Poluição ambiental - $\mathrm{O}$ risco ambiental diz respeito à contaminação de elementos do meio ambiente, água e ar, principalmente com agentes químicos. A poluição aérea, principalmente dos grandes centros que pode contribuir para a incidência de câncer está ligada à queima de produtos combustíveis.

Radiação - Principalmente após a explosão das bombas atômicas em Hiroshima e Nagasaki e com a observação de pacientes que se submetem à radioterapia, constatou-se que a radiação ionizante pode induzir ao câncer no homem. Além desta, também a radiação ultravioleta (proveniente principalmente do sol), já está associada à origem de alguns tipos de câncer.

Suscetibilidade genética - Atualmente sabe-se que o risco de câncer é grande quando existe um histórico familiar da doença, o que levanta a hipótese de uma suscetibilidade genética. Tal hipótese é reforçada quando é observado, por exemplo, o câncer de pele cuja incidência é maior em pessoas que possuem pele com pigmentação clara. Além disso, o risco é ampliado quando o indivíduo possui síndromes hereditárias pré-cancerosas, como o xeroderma pigmentoso, a neurofibromatose, a síndrome de Bloom etc.

Também é importante salientar a relação existente entre o sistema imunológico e os agentes cancerígenos, sendo que esse sistema está diretamente relacionado com os estados emocionais do indivíduo. Pessoas que tenham sofrido grandes perdas, que sofrem contínuos padrões de distresse, que tenham incapacidade ou inabilidade extremada em lidar com emoções (geralmente reprimindo-as) etc., não irão necessariamente desenvolver um tumor, mas debilitarão seu organismo, o que facilita a atuação de agentes cancerígenos.
Sentimentos de desesperança e desistência ocorrem com mais freqüência em indivíduos já estressados e, quando portadores de câncer, essa postura de "desistência" encontra um campo favorável, uma vez que as defesas naturais do corpo se encontram diminuídas e a relação corpo-mente-emoção, fica portanto, comprometida... o "estresse crônico" deprime o sistema imunológico responsável pela destruição de células cancerosas ou microorganismos estranhos ao corpo. Criando condições propícias para o aparecimento do câncer (Ferreira, 1994, p. 173).

É interessante notar que, muitas pessoas portadoras de tumores, desenvolvem a doença sem terem um contato direto com agentes causadores de câncer e, nem possuem um histórico familiar da doença. Tais casos são um convite para uma observação mais profunda em relação a esta patologia, sendo possível destacar os aspectos psicológicos implicados. Parece ocorrer em tais casos um grande conflito no tocante a Eros/Thanatos ou, luta/desistência. Ao estudar o câncer, é possível observar em alguns momentos, uma busca pela morte, uma vontade de consumir-se a si próprio como afirma Chabner (1993, p. 1.037): “os tumores destroem o homem de maneira peculiar e apavorante, já que a carne de sua própria carne de alguma forma se torna proliferativa, agressiva predatória e ingovernável". Entretanto, esta mesma atitude "agressiva" do tumor, descrita por Chabner (1993), pode ser entendida como uma luta pela vida, numa espécie de conflito self/ego, como se uma parte do indivíduo (self), tentasse de maneira desesperada "proliferar para sobreviver", visto que, o organismo (ego) já desistiu desse movimento. Podemos observar isso, no modo de organização de algumas células neoplásicas.

\begin{abstract}
Muitas células malignas preservam as propriedades de crescimento e antigênicas características das células fetais, secretam proteínas características dos tecidos fetais (como a $\alpha$-fetoproteína dos carcinomas hepatocelulares e dos tecidos de células germinativas) e parecem ficar presas em um estágio inicial de diferenciação que lembra um estágio específico no desenvolvimento normal do órgão (Chabner, 1993, p. 1.038).
\end{abstract}

Não é possível afirmar categoricamente que os tumores cancerígenos tenham, além das causas físicas, químicas e biológicas, também causas psicológicas. Porém, pode-se afirmar, dentro de uma compreensão somatopsicodinâmica de homem que é necessária a combinação desses elementos para a ocorrência e a proliferação dos tumores. Segundo Ferreira (1994, p. 173) "para o aparecimento de um tumor são necessárias três condições: 1) Um conflito pessoal muito dramático; 2) Conflito prolongado; 3) Conflito acompanhado de um estado de solidão e fechamento psicológico".

$\mathrm{Na}$ atuação prática em hospitais gerais com pacientes oncológicos, observa-se que um dos principais fatores geradores de tensão, e logo, de angústia, é a incerteza quanto ao futuro, devido 
principalmente à demora no estabelecimento de um plano terapêutico eficaz. Infelizmente a elaboração de um plano terapêutico não é tão simples de ser realizada como pode parecer. De acordo com Salmon (1993), pelo menos três elementos centrais devem ser levados em consideração ao se criar um plano terapêutico:

1. O diagnóstico - Onde o maior problema está em diagnosticar tumores indiferenciados, ou ainda pouco diferenciados. Atualmente as análises histológicas cada vez mais precisas possibilitam determinar mais facilmente se os tumores são linfomas, melanomas, carcinomas, sarcomas etc.

2. O estagiamento - Tem por objetivo averiguar o volume do tumor, bem como a presença ou não de metástases em outros pontos do organismo. (Cada vez mais este processo está sendo realizado com técnicas menos invasivas ao paciente, sendo utilizadas principalmente a radiografia, a ultra-sonografia, a tomografia computadorizada, a ressonância magnética nuclear, a endoscopia etc.).

3. A avaliação global - É nesse momento que se realiza a definição da modalidade terapêutica a ser utilizada com o paciente. Aqui, a presença multidisciplinar se faz necessária com uma maior intensidade, visto que existe a possibilidade de serem realizados tratamentos conjuntos (não só de ordem médica), sendo que, um dos principais fatores a ser avaliado neste momento é a relação custo/beneficio do tratamento para o paciente.

Após a realização dessas três etapas para a definição de um plano terapêutico, o paciente pode então, ser submetido a uma abordagem terapêutica específica. Atualmente existem três modalidades terapêuticas clássicas para o combate ao câncer: a cirurgia, a radioterapia, e a terapia clínica. Porém, além destas modalidades fundamentais para o tratamento do câncer, existe uma constante busca por novas abordagens que contribuam para uma intervenção mais efetiva sobre a patologia, visto que a visão puramente biológica do câncer está cada vez mais sendo substituída por outra, que leva em consideração, principalmente o ser (e o meio em que ele está inserido) envolvido com a patologia.

Apesar de estarmos distantes de esgotar totalmente nossa compreensão sobre o tema, um fator está comprovado em relação ao câncer, no tocante a aspectos psicológicos do sujeito portador da doença: a vontade de continuar lutando, aliada a uma conscientização do quadro, e uma efetiva participação no processo terapêutico são fundamentais para o sucesso do mesmo. Como afirma Carvalho (1994, p. 141), referindo-se a um estudo realizado com pacientes oncológicos:

Os pacientes do primeiro grupo, aqueles que evoluiam melhor, tinham também como característica achar que de alguma forma podiam influenciar o curso de suas doenças. Adotavam uma atitude muito mais ativa em relação a suas vidas $e$ também em relação à doença e aos tratamentos médicos. Eram pessoas mais participativas, que diferentemente da grande maioria dos pacientes não viam o processo de cura como algo a que o indivíduo se submetesse passivamente, mas como algo de que podiam participar de forma ativa.

\section{O ATENDIMENTO PSICOLÓGICO À FAMÍLIA ENLUTADA}

Todas as famílias ao longo de suas histórias passam por momentos de crise que desestruturam uma certa ordem estabelecida. A duração deste momento, bem como as consequiências que trará, irá depender de fatores como: a preparação da família para o evento, a estrutura social na qual está inserida, a intensidade e a forma como tudo transcorreu etc.

A morte de um dos membros da família é um desses momentos marcantes de crise pelos quais ela passará. A forma como a morte é encarada varia drasticamente de cultura para cultura, e de uma época para outra. Por mais suave que seja essa transição, a morte sempre tem algo de doloroso que necessita ser vivenciado. Por esta razão (para aliviar a "dor" de quem sofre uma perda, e para ajudá-lo a adaptar-se a uma nova realidade), as diversas sociedades criaram formas específicas de rituais (ritos de passagem) para esse momento. No entanto, apesar de existirem formas específicas para se lidar com a morte em cada cultura, cada família dará uma roupagem própria a esta forma, interpretando-a à sua maneira.

\begin{abstract}
A família, longe de ser uma intermediária, é a força primária operando nesses momentos - primária não apenas porque é ela, e não a cultura, que determina a qualidade emocional dessas ocasiões (e, conseqüentemente o sucesso da passagem), mas também porque é a família, mais do que a cultura que acaba determinando os ritos a serem cumpridos. As famílias são muito menos determinadas pelos costumes de sua cultura e por sua maneira de fazer as coisas do que são seletivas, de acordo com suas próprias características e patologias, em relação ao repertório cerimonial de sua cultura (Friedman, 1995, p. 106).
\end{abstract}

Desse modo, compreende-se o quanto as famílias são importantes nestes rituais, visto que, a energia necessária para o ritual emana dela, sendo moldada pela cultura, e não ao contrário. Assim a condução do luto precisa partir daquilo que emana desse núcleo que vivencia mais intensamente esse processo.

O processo de luto, em nossa cultura ocidental, até bem pouco tempo (e ainda hoje, só que mais raramente), era bastante facilitado pelos velórios que eram assistidos por toda a comunidade. As pessoas mesmo que relativamente desconhecidas, vinham prestar suas condolências à família, permanecendo por horas a fio no local, apenas em silêncio (visto que diante da morte, não há o que dizer). Ocorria também, de vizinhos assumirem as tarefas da casa durante esse período, que podia durar dias, desse modo as pessoas enlutadas viam-se livres e acolhidas pelo coletivo para vivenciar o seu processo, o que de uma forma geral, trazia uma boa elaboração da perda (até mesmo por parte da comunidade). 
Porém, nos dias de hoje, onde o tempo transformou-se um bem precioso, tais rituais tornaram-se inviáveis. A antiga presença física para "dar força" é, cada vez mais, substituída por telefonemas e cartões de condolências. A própria morte não é mais vivenciada em casa, ocorrendo geralmente em um hospital e, com um velório rápido sendo realizado no próprio cemitério horas antes do enterro, quase apenas para cumprir um protocolo. A própria sociedade assim, se prejudica, pois o não contato com a morte leva a um desconhecimento sobre a mesma e logo: ao medo.

Entretanto, mesmo que de uma forma precária, as famílias e os próprios indivíduos desenvolvem formas específicas de lidar com as perdas. O terapeuta que trabalha com estas questões, deve cuidar para não deixar que suas próprias ansiedades e fantasias interponham-se ao seu trabalho, querendo que as pessoas vivenciem ou expressem abertamente seu processo de luto. Ao invés disso, precisa estar atento e intervir mais enfaticamente, somente quando perceber que algo está atrapalhando o processo. Nunca é demais ressaltar que cada pessoa tem seu momento e forma de lidar com o luto, e, quando isso não ocorre, aí sim uma intervenção terapêutica mais enfática se faz necessária. De acordo com Stedeford (1986, p. 141),

Os profissionais que estiveram intimamente ligados ao tratamento do paciente terminal desejam continuar o contato com a família, por mais algum tempo, quando possível. Eles sentem o pesar sobre a morte do paciente, e a última ajuda que podem prestar é ver se as pessoas mais ligadas ao falecido estão seguindo um processo de luto normal... pelo menos um dos interessados no caso - o clínico geral, enfermeira -chefe, a assistente social ou o sacerdote - deveria continuar a agir como uma espécie de monitor permanecendo como uma figura de apoio a distância se tudo estiver correndo bem, porém pronta a intervir se as necessidades dos parentes e amigos não estiverem sendo satisfeitas.

Stedeford (1986) coloca ainda que qualquer tipo de tristeza, da mais simples à mais grave, deixa a pessoa debilitada e que dois componentes básicos são percebidos nessa manifestação, variando de magnitude e intensidade: uma resposta emocional e a interrupção de uma atividade habitual. Dessa forma, estes dois componentes já podem ser esperados pelo profissional que trabalha com o luto, constituindo-se em elementos que precisam ser levados em consideração durante a condução desse processo. De maneira geral, nesse momento o importante é tratar o enlutado de maneira honesta, sincera e clara, evitando-se contornos e mecanismos de compensação, compreendendo que as manifestações (dóceis ou agressivas) que são exteriorizadas fazem parte apenas de um momento de transição, podendo ser, muitas vezes, pedidos de ajuda disfarçados.

Assim a importância de um bom acompanhamento durante o período de luto, diz respeito principalmente à prevenção, evitando que emoções presas ou,mal elaboradas venham a trazer problemas futuros. Se a incorporação da perda é mal feita ou simplesmente ignorada, o indivíduo, em um breve espaço de tempo, pode apresentar quadros patológicos como: desajustes sociais, estados depressivos, doenças psicossomáticas, reprodução de um drama familiar anterior, incorporação do papel do falecido etc. Conforme colocado por Lindemann citado por Bromberg (1994, p. 246).

Freud já em 1917 demonstrava que para concluir o trabalho de luto a libido deve ser retirada do objeto perdido e transferida para um novo objeto... a aceitação da perda, e o estabelecimento de novas relações objetais são condições fundamentais para a elaboração do luto.

Desse modo, encarar, compreender e aceitar a perda, fica mais leve quando nos deparamos com um dado da realidade. Assim, o trabalho com familiares enlutados torna-se mais fácil quando a morte já ocorreu e já se constitui em fato. Entretanto, quando a morte do parente ainda é uma expectativa, esse processo pode tornar-se mais complicado. Tal situação é ambivalente, dando margem a duas possibilidades: uma, geradora de alívio, pois a família tem tempo para compreender e processar o que ainda vai acontecer, podendo realizar uma boa despedida do membro que irá falecer, e outra, geradora de angústia, pois a família pode ter a percepção de estar traindo o ente que ainda não morreu, desejando ou antecipando sua morte.

Os que sobrevivem ao luto antecipado, começam a experimentar reações de luto antes mesmo da morte do ente querido. Uma delas é o senso de culpa, resultando do fato de que se encontram planejando seu próprio futuro sem o ente querido, mesmo antes da morte dele. Esta "preocupação a nível consciente”, pode ser útil psicologicamente, mas, socialmente, a família e amigos podem não ter a capacidade de compreender esta reação (Franklin, 1997, p. 118).

O profissional que trabalha com a situação de luto antecipado precisa trazer para o foco da intervenção os benefícios que essa situação traz, principalmente, o benefício de ter mais tempo para se preparar e poder realizar uma boa despedida, aproveitando para resolver (caso haja) algum problema ainda pendente. Em casos assim, também é importante baixar os níveis de ansiedade decorrentes das fantasias que poderão surgir, geralmente em torno das culpas, dos deveres ou responsabilidades, isso nem sempre é fácil para o profissional, mas pode ser feito, estando-se atento ao discurso do familiar enlutado, pontuando onde e como ele coloca elementos a mais, do que realmente está acontecendo.

A situação de morte iminente, porém não realizada, talvez seja uma das crises mais angustiantes pelas quais uma família possa passar. O problema maior encontra-se na frustração decorrente da impotência vivenciada perante o "o que fazer?" e o 
“quando vai ser?". O tempo prolongado dessas situações geralmente acaba sendo o principal inimigo, pois vai debilitando gradativamente a resistência dos envolvidos. Boss (1998) define tais situações como "perdas ambíguas", onde o que ocorre é uma indefinição da situação, ou excessiva demora na sua definição.

Outro fenômeno marcante nos casos de famílias enlutadas pela morte ou eminência de morte de um de seus membros é a incorporação de diferentes papéis diante do fato. Assim, existem os inconformados, os apáticos, os desesperados, sendo comum, porém, a existência de um papel bem determinado: o forte. Em praticamente todas as famílias destaca-se nesse momento, um ou mais membros que reagirão à situação de uma forma altamente prática, eficiente e racional, cuidando de tudo para que os outros membros da família possam vivenciar sua dor. Muitas vezes o terapeuta pode "se utilizar" dessa pessoa para poder "entrar" no âmago da família enlutada, contando com seu auxílio para trabalhar junto aos outros familiares. Entretanto esta "força" precisa ser entendida como algo momentâneo, e não se deve cair no erro de acreditar que o indivíduo que incorporou esse papel não necessite de auxílio para a elaboração de seu luto. Tal indivíduo precisa ser incentivado a, no momento oportuno, também realiza-lo, pois como ressalta Caplan (1980, p. 310),

\begin{abstract}
As pessoas que parecem ajustar-se mais estoicamente a uma morte são, a longo prazo, as mais afetadas por ela. Vez por outra observamos pessoas que encaram aparentemente uma perda com fortaleza e coragem incomuns. Elas não se deixam abalar pelo infortúnio... Não choram nem se mostram preocupadas com as recordações $e$ pensamentos sobre as pessoas que amavam $e$ perderam... Mas eram essas pessoas aparentemente "corajosas" as que, com o tempo, eram mais marcadas pela morte.
\end{abstract}

O trabalho psicológico em hospitais gerais com famílias enlutadas.

O trabalho com familiares enlutados, de pacientes terminais com câncer em hospitais gerais não é fácil. O próprio trabalho de luto em si já apresenta suas dificuldades, e, se ligarmos a isso, o estigma de uma doença secular, um ambiente hospitalar aversivo junto, a insegurança de alguns profissionais que muitas vezes negam-se a fornecer diagnósticos e prognósticos verdadeiros ao paciente nessas situações, colocando para a família toda a responsabilidade sobre a decisão de informar ou não o paciente, teremos então, um universo riquíssimo para a criação das mais variadas fantasias, surgimento de conflitos e quadros patológicos. Os problemas que o profissional de psicologia enfrenta nessas situações são vários: desde a incerteza do tempo de internação do paciente, até a falta de um setting específico para realizar os atendimentos, passando, muitas vezes, por um ambiente de trabalho multidisciplinar fragmentado, onde as informações vêm e vão em constantes contradições, servindo apenas, para ampliar a tensão e angústia dos pacientes internados, bem como de seus familiares.

Porém, ficar apenas listando os problemas com que qualquer profissional se depara ao entrar em um hospital geral, não resolve a situação. Como a resolução destes problemas parece ainda estar longe de ser alcançada, no momento, somos obrigados a nos render aos fatos presentes e realizarmos o melhor trabalho possível dentro daquilo que nos é colocado. Dado as diversas dificuldades que o profissional encontrará para realizar o atendimento, o primeiro passo é tentar garantir ao máximo o foco do trabalho, centrando-se especificamente na crise que está sendo vivenciada naquele momento, deixando outros fatos mais estruturais da dinâmica familiar, para um momento posterior (quando possível), ou fazendo um encaminhamento para uma psicoterapia após a internação. É neste sentido que Pincus (1989, p. 230) afirma:

\begin{abstract}
A segunda característica importante de toda terapia breve sobre o trabalho da perda é a forte ênfase na crise de perda. Não estamos tratando de uma doença ou tentando interferir em distúrbios de personalidade, embora seja imperativo compreender que problemas de personalidade e do seu padrão de relações foram intensificados pela crise. Eles não podem ser resolvidos numa terapia breve, mas o problema específico que cada pessoa introduz na crise da perda tem de ser apreendido pelo terapeuta e pelo próprio enlutado.
\end{abstract}

Um elemento que constantemente aparece quando se trabalha com familiares de pacientes terminais com câncer em hospitais, são as fantasias decorrentes da patologia. Muitos evocam o medo de também desenvolverem a doença através da suscetibilidade genética, também surgem nos discursos o medo e a angustia de ver seus entes queridos passarem os últimos dias sofrendo, principalmente com dores físicas ou, de serem submetidos a tratamentos drásticos como a quimioterapia, sem efetivamente ter algum ganho significativo. Quando essas situações vêm ao foco da intervenção, deve-se buscar separar realidade da fantasia, clarificando ao familiar o quanto de cada um ele está colocando em seu discurso. Entretanto, não podemos esquecer que efetivamente muitas pessoas, ao sofrerem uma perda grande, acabam por incorporar o papel do falecido, inclusive muitas vezes com sua mesma patologia, ou outras de intensidade semelhante. Dessa forma, pode-se até sugerir ao familiar que realize ele próprio exames num caráter preventivo, como qualquer pessoa pode realizar, bem como sugerir um acompanhamento psicoterápico para lidar mais profundamente com tais questões.

Da mesma forma como é importante centrar a atenção do atendimento sobre a crise que está acontecendo no momento, outro fator importante a ser enfatizado é, buscar diminuir a ansiedade dos familiares (e do próprio paciente), para que o trabalho transcorra de uma maneira mais suave. Infelizmente a própria situação hospitalar é por si só uma situação 
geradora de ansiedade, sendo que um dos principais "geradores" é a falta de informação sobre o que esta acontecendo.

Alguns profissionais da área da saúde em hospitais, embora com grande conhecimento técnico sobre a situação hospitalar, são na verdade imaturos em relação a como lidar com pacientes em situações graves, existindo um grande medo de um "enfrentamento" por intermédio de um questionamento de seu trabalho, assim sendo, evitam ao máximo ter que dar explicações sobre o que estão fazendo. Esta forma de agir faz com que, devido às incertezas, o paciente e seus familiares fiquem bastante regredidos, numa postura infante de submissão à autoridade imposta. Tornam-se "mais dóceis", e logo, questionam menos, o que é erroneamente entendido por tais profissionais como "colaboração com o tratamento".

O maior problema nesta situação é que, à medida que o silêncio vai perdurando, a ansiedade vai aumentando, interferindo diretamente no processo terapêutico das pessoas envolvidas. A família por ficar regredida, pode acabar vendo a figura do psicólogo como alguém esclarecedor que irá sanar todas as dúvidas ao respeito dos procedimentos hospitalares. $\mathrm{O}$ importante para o psicólogo, neste momento, é não se deixar levar pelas próprias fantasias, querendo ajudar a família, agindo por ela. Ao invés disso é preciso incentivar os familiares (e o próprio paciente), a participarem de forma ativa dessa situação, na qual eles são os personagens principais, e questionarem os devidos profissionais a fim de se inteirarem de tudo o que se passa no seu caso durante o período de internação.

Do mesmo modo que a falta de informação, a falta de um lugar onde os indivíduos possam expressar seus sentimentos de forma adequada também é um elemento de dificuldade para o psicólogo. Entretanto, como a principal atividade a ser realizada, frente à morte iminente é a do acolhimento, em uma situação de emergência, é irrelevante o local em que esse acolhimento se dará. Porém, o que não é irrelevante é a necessidade de existir um lugar específico no hospital, onde o profissional possa realizar seu atendimento de maneira adequada.

Visto que, frente à morte, não há o que ser feito, muitas vezes, o que as pessoas enlutadas precisam é, principalmente em um hospital, apenas a compreensão da sua forma de externalizar o luto. Como afirma Freud citado por Pincus (1989, p. 227):

\footnotetext{
Embora o pesar implique graves afastamentos da atitude normal diante da vida, não nos ocorre jamais encará-lo como uma condição mórbida e submeter a pessoa enlutada a um tratamento médico, estamos seguros que após um lapso de tempo isso será superado, e consideramos desaconselhável, e até mesmo prejudicial qualquer interferência.
}

Claro que, como foi colocado ao longo deste trabalho, na época em que Freud escreveu este texto
(Luto e melancolia), a sociedade possuía formas mais definidas para apoiar o enlutado. Entretanto a colocação de Freud é interessante no sentido de alertar que as pessoas reagem de formas diferentes nos seus processos de luto e, muitas vezes precisam, apenas ser respeitas nestas formas de manifestação. Assim, mesmo hoje, quando a sociedade é inábil em lidar com a morte, o psicólogo em um hospital deveria buscar assumir uma postura mais observadora do que impositora na situação de luto, procurando interferir somente no sentido de conduzir o processo, ao invés de induzi-lo e, mesmo assim somente quando autorizado. Essa autorização raramente é expressa abertamente, por isso o psicólogo precisaria ter a sensibilidade para perceber quando ela ocorre.

Porém, dado a dinâmica de um hospital geral, nem sempre o psicólogo tem a disponibilidade, o tempo ou a liberdade para poder "deixar fluir" essa percepção. Geralmente as situações são emergenciais, onde a tomada de decisões rápidas e, muitas vezes práticas, é a prioridade. Neste sentido, é preferível pecar pela ação, do que pela omissão e, embora cada caso seja invariavelmente um caso diferente, o profissional que atua com familiares enlutados de pacientes terminais com câncer pode melhorar seu trabalho se tiver internalizado alguns procedimentos básicos para utilizar em seus atendimentos.

\section{SUGESTÕES DE PROCEDIMENTOS PARA O ATENDIMENTO}

Tendo como base o que foi explanado até este momento e objetivando auxiliar o profissional em Psicologia que trabalha com pessoas enlutadas no cotidiano de um hospital, desenvolveu-se um roteiro prático de procedimentos específicos que auxiliam no atendimento psicológico para essas situações. Para tanto, nesse roteiro buscou-se dividir tais procedimentos, em momentos, ou etapas, que, de acordo com observações empíricas, ocorrem de uma maneira regular e contínua. Entretanto, é claro, tais momentos não devem ser vistos como lineares, fechados ou acabados, nem devem ocorrer em um número " $x "$ de atendimentos específicos. Ao invés disso, eles se interpõem e se complementam, podendo acontecer ou não, sempre de acordo com a demanda trazida pelos enlutados em acompanhamento. Desse modo, para realizar o acompanhamento psicológico com familiares enlutados de pacientes terminais em hospitais, sugere-se a observação dos seguintes momentos:

$1^{\circ}$ momento: Dar acolhimento, deixar a pessoa falar, desabafar, chorar etc. O importante para que isto ocorra com eficácia é ter um vínculo estabelecido. Ter acompanhado o paciente (e os familiares) durante o seu período de internação pode auxiliar, mas, se isto não foi possível, o simples "estar presente" pode ser o suficiente. Caso não seja, devem-se buscar outros meios para estabelecer o vínculo.

$2^{\circ}$ momento: Acolher as fantasias dos parentes como: raivas, culpas, temores etc. aceitando sem grandes contradições no momento (até porque não se 
sabe ainda o quanto é fantasia e o quanto é realidade), mas também sem dar maiores reforços ao discurso.

$3^{\circ}$ momento: Falar sempre a verdade em relação ao prognóstico do paciente. Isto é importante principalmente para manter o vínculo com a família e estabelecer laços de confiança, aqui deve-se também incentivar ao resto da equipe de saúde a desenvolver a mesma postura.

$4^{\circ}$ momento: Descobrir a existência de alguém que possa resolver os problemas práticos da situação. Geralmente há alguém na família que incorpora o papel do "forte", e se encarrega dos problemas mais burocráticos. Esse "forte", no momento oportuno, precisará ser lembrado de que não deverá ser "forte" o tempo todo, sob pena de acabar carregando um fardo maior do que suas possibilidades permitem. Nesse momento, pessoas que não sejam tão ligadas ao paciente podem ser importantes, principalmente para dar apoio aos familiares (namorados, amigos, vizinhos, parentes distantes etc).

$5^{\circ}$ momento: Poupar a família do excesso de ajuda externa. Aqui o psicólogo deve controlar sua própria ansiedade no ímpeto de querer ajudar. O excesso de estímulos vindo do exterior do núcleo familiar pode ser estressante. Cada família tem sua dinâmica, tempo, e forma para "digerir" seus processos, isso deve ser respeitado. O importante neste momento é agir mais com a observação. e o enlutado deve ser conscientizado disso para que não se sinta abandonado pelo psicólogo.

$6^{0}$ momento: Evitar a criação de fantasias de cura milagrosa (isso não significa resignação ao diagnóstico, pode-se buscar uma segunda opinião ou até outras formas de tratamento), a realidade deve ser encarada sob pena de uma frustração maior posteriormente. (Lembrando que aqui, trata-se de uma doença agressiva e de pacientes em estado terminal.)

$7^{\mathbf{0}}$ momento: Incentivar a família a respeitar e também vivenciar junto com o paciente o tempo que resta, respeitando os limites e as vontades deste (o que não significa se submeter a qualquer imposição vinda do paciente, sob o fantasma de um futuro remorso ou culpa). Este também é o momento do "deixar ir", de se livrar das mágoas do passado, de perdoar. Para tanto é indicado que o paciente esteja ciente da sua condição. Isto deve ocorrer somente se for espontâneo, agir de forma artificial não trará os benefícios esperados.

$8^{\circ}$ momento: Esclarecer aos familiares não tão ligados ao paciente terminal que manifestações emocionais vindas para eles daqueles que estão mais ligados ao paciente não devem ser entendidas como agressões pessoais. Alguns parentes podem querer atacar, destruir, a situação ou seus medos e angústias internas; como não conseguem acabam, deslocando sua agressividade para um outro objeto mais próximo, no caso a família. (Esse procedimento precisa do mesmo modo ser realizado com a equipe de saúde.) A família também deve ser instruída a acolher e a incentivar a afloração dos sentimentos internos de seus membros (dentro de limites aceitáveis), para que não venham a causar danos futuros. 9o momento: É o momento de começar a contabilizar não só as perdas, mas, sobretudo, os ganhos da situação. Aqui, pode-se incentivar a família a fazer uma avaliação geral de como entrou, como está, e de como sairá da situação. Também é o momento onde se pode realizar o encaminhamento para a psicoterapia caso necessário.

Tais procedimentos podem, num primeiro instante, parecer idealizados e difíceis de serem aplicados no cotidiano de um hospital geral. Entretanto, o profissional que pretende aplicá-los deve ter a consciência de que terá de adaptá-los a sua realidade cotidiana, ou seja, não ter acesso a um setting adequado, ter acesso apenas a alguns elementos da família, correr o risco de ter seu trabalho abreviado ou alongado dependendo das condições do paciente etc. Assim sendo, esse roteiro prático para atuação nesse contexto, desde que não seja utilizado de forma rígida ou estereotipada, é de grande benefício para os profissionais que trabalham na área hospitalar, ainda tão carente, em nosso país, de uma literatura teórica e prática sistematizada.

\section{REFERÊNCIAS}

Boss, P. (1998). A perda ambígua. Em F. Walsh \& M. Mcgoldrick (Orgs.), Morte na família: sobrevivendo às perdas (pp. 180-192). Porto Alegre: Artes Médicas.

Bromberg, M. H. P. F. (1994). Famílias enlutadas. Em M. M. M. J. Carvalho (Coord.), Introdução a psiconcologia (pp. 243-259). Campinas: Psy.

Caplan, G. (1980). Princípios de psiquiatria preventiva. Porto Alegre: Zahar.

Carvalho, V. A. (1994). Programa Simonton: uma experiência no Brasil. Em M. M. M. J. Carvalho (Coord.), Introdução a psiconcologia (pp. 141-159). Campinas: Psy.

Casciato, D. A. \& Lowitz, B. B. (Org.) (1991). Manual de oncologia clínica. Rio de Janeiro: Medsi.

Chabner, B. A. (1993). Introdução. Em J. B. Wyngaarden; L. H. Smith \& J. C. Bennett Cecil: Tratado de medicina interna (19. ed.). (pp. 1.048-1.051). Rio de Janeiro: Guanabara Koogan.

Ferreira, M. L. (1994). Trabalho corporal e o câncer. Em M. M. M. J. Carvalho (Coord.), Introdução à psiconcologia (pp. 173-183). Campinas: Psy.

Foucault, M. (1999). História da loucura (6. ed). São Paulo: Perspectiva.

Franklin, J. (1997). Apoio ao enlutado no cuidado paliativo. Em C. M. Nascimento-Sculze (Org.), Dimensões da dor no câncer (pp. 115-123). São Paulo: Rode.

Friedman, E. H. (1995). Sistemas e cerimônias: uma visão familiar dos ritos de passagem. Em M. Mcgoldrick \& B. Carter (Orgs.), As mudanças no ciclo de vida familiar (pp. 102-115). Porto Alegre: Artes Médicas.

Muraro, R. M. (1991). Breve introdução histórica. Em: H. Kramer \& J. Sprenger (Orgs.), $O$ martelo das feiticeiras: Malleus maleficarum (5. ed.) (pp. 5-17). Rio de Janeiro: Rosa dos Tempos.

Pincus, L. (1989). A família e a morte: como enfrentar o luto. Rio de Janeiro: Paz e Terra.

Pitta, A. (1999). Hospital: dor e morte como ofício. São Paulo: Hucitec. 
Salmon, S. E. (1993). Princípios do tratamento do câncer. Em J. B. Wyngaarden; L. H. Smith \& J. C. Bennett (Orgs.), Cecil: Tratado de medicina interna (19. ed.) (pp. 1.069-1.090). Rio de Janeiro: Guanabara Koogan.

Stedeford, A. (1986). Encarando a morte. Porto Alegre:

Recebido: 22.10 .2002

Revisado:26.06.2003 Artes Médicas.

\section{Sobre o autor}

André Luiz Picolli da Silva: Psicólogo Mestrando do Programa de Pós-Graduação em Psicologia da Universidade Federal de Santa Catarina. Endereço para correspondência: Rua Barra Velha, n. 141 - Bela Vista I São José - SC CEP: 88110-160 E-mail: kuluzan@hotmail.com. 

